\title{
Onychomadesis and hand, foot and mouth disease - is there a connection?
}

E Haneke (haneke@gmx.net)1,2,3,4

1. Dermatology Practice "Dermaticum”, Freiburg, Germany

2. Department of Dermatology, Inselspital, University of Bern, Bern, Switzerland

3. Dermatology Centre "Epidermis", Instituto CUF, Porto, Portugal

4. Department of Dermatology, Academic Hospital, University of Ghent, Ghent, Belgium

Citation style for this article:

Haneke E. Onychomadesis and hand, foot and mouth disease - is there a connection?. Euro Surveill. 2010;15(37):pii=19664. Available online: http://www. eurosurveillance.org/ViewArticle.aspx?Articleld $=19664$

Article published on 16 September 2010

Onychomadesis is the spontaneous separation of the nail plate from the matrix, a kind of proximal onycholysis, and is a common phenomenon due to arrest of nail formation for a certain period. Short-term slowing down of nail formation leads to Beau's lines, while long-term stop of nail growth will cause onychomadesis and even nail shedding.

Hand, foot and mouth disease (HFMD) is a relatively common viral infection often seen as small epidemics in autumn or spring. It is characterised by oval blisters around the nails, on palms and soles with the long axis of the vesicles running along the dermatoglyphs, and by aphthoid small ulcerations of the oral mucosa. Small children are mostly infected, but probably many parents are non-symptomatic carriers as the condition usually runs a very mild course.

A relationship between HFMD and onychomadesis has been proposed already ten years ago $[1,2]$, but only recently Finnish and Spanish authors observed a sufficient number of children developing onychomadesis approximately six weeks after they had suffered from HFMD [3-6] that makes this appear more than a chance association. An article by Guimbao and coworkers published in today's issue of Eurosurveillance describes an outbreak of onychomadesis in Saragossa (Spain) in July 2008 [7]. The authors noticed that a large proportion of the patients had had HFMD a few weeks before and initiated a retrospective cohort study that indicated a link between the two diseases. They conclude that onychomadesis may be a late complication of HFMD.

From these authors' and the previous ones' observation there is no doubt that there is a temporal link between HFMD and onychomadesis.

The question is now: Is the virus, more specifically the enterovirus causing HFMD, really the cause of onychomadesis? While the number of onchomadesis cases in these young patients suggests it, could it have been caused rather by the inflammation so close to the nail matrix? Or could it have been due - of course much less likely - to intensive hygienic measures taken after HFMD broke out in the nurseries? It is well known that maceration favours Candida infections and allergic contact dermatitis, which can also cause onychomadesis [8]. The timing of viral determination from stools and pharynx samples taken one to three weeks after the diagnosis of onychomadesis and thus between seven and nine weeks after the disease, appears to be very late considering that HFMD is a self-limited condition healing spontaneously within a week. In order to solve the problem, more viruses that could potentially be associated with the two conditions will need to be analysed, with viral analyses of nail specimens (e.g. swabs from under the proximal nail fold) performed in the early course of the disease.

However, onychomadesis per se is certainly not infectious; instead, it may be the consequence of an infectious disease often localised very close to the nail. Another explanation would be that HFMD has a more severe impact on the general condition of the small children so that it causes a nail growth arrest for a period sufficiently long to result in onychomadesis.

\section{References}

1. Clementz GC, Mancini AJ. Nail matrix arrest following handfoot-mouth disease: a report of five children. Pediatr Dermatol. 2000;17(1):7-11.

2. Bernier V, Labrèze C, Bury F, Taïeb A. Nail matrix arrest in the course of hand, foot and mouth disease. Eur J Pediatr. 2001;160(11):649-51.

3. Osterback R, Vuorinen T, Linna M, Susi P, Hyypiä T, Waris M. Coxsackievirus A6 and hand, foot, and mouth disease, Finland. Emerg Infect Dis. 2009;15(9):1485-8.

4. Redondo Granado MJ, Torres Hinojal MC, Izquierdo López B. Brote de onicomadesis posvirica en Valladolid. [Post viral onychomadesis outbreak in Valladolid]. Spanish. An Pediatr (Barc). 2009;71(5):436-9.

5. Blomqvist S, Klemola P, Kaijalainen S, Paananen A, Simonen $\mathrm{ML}$, Vuorinen T, et al. Co-circulation of coxsackieviruses A6 and $A 10$ in hand, foot and mouth disease outbreak in Finland. J Clin Virol. 2010;48(1):49-54.

6. Davia JL, Bel PH, Ninet VZ, Bosch IF, Salazar A, Gobernado M. Onychomadesis outbreak in Valencia, Spain associated with hand, foot, and mouth disease caused by enteroviruses. Pediatr Dermatol. 2010 Jun 9. [Epub ahead of print]

7. Guimbao J, Rodrigo P, Alberto MJ, Omeñaca M. Onychomadesis outbreak linked to hand, foot, and mouth disease, Spain, July 2008. Euro Surveill. 2010;15(37):pii=19663. Available from: http://www.eurosurveillance.org/ViewArticle. aspx?Articleld=19663

8. Tosti A, Piraccini BM. Paronychia. In: Amin S, Maibach HI. Contact Urticaria Syndrome. Boca Raton, Florida: CRC Press; 1997. p.267-78. 